\title{
Relationship between dystocia and the lactation number, stillbirth and mastitis prevalence in dairy cows
}

\author{
Vida Juozaitiene ${ }^{1}$, Arunas Juozaitis ${ }^{1}$, Arvydas Kardisauskas ${ }^{1}$, Judita Zymantiene ${ }^{2}$, \\ Vytuolis Zilaitis ${ }^{3}$, Ramunas Antanaitis ${ }^{3}$, Modestas Ruzauskas ${ }^{2}$ \\ Lithuanian University of Health Sciences, ${ }^{1}$ Faculty of Animal Husbandry Technology, \\ Department of Animal Breeding and Nutrition, ${ }^{2}$ Faculty of Veterinary Medicine, \\ Department of Anatomy and Physiology, ${ }^{3}$ Faculty of Veterinary Medicine, \\ Large Animal Clinic, Kaunas, Lithuania
}

Received March 16, 2017

Accepted December 19, 2017

\begin{abstract}
Successful management of lactating dairy cows needs to integrate the programs of herd reproduction and health. The objectives of this study was to determine the relationship of dystocia, stillbirths, and the prevalence of mastitis in dairy cow herds. A total of 559304 Lithuanian Black and White dairy cows were evaluated in relation to calving ease and stillbirths. Moreover, 1498 cows from the aforementioned group were tested for the milk somatic cell count and the presence of udder microbiota in the post partum period. The majority of extremely difficult births were estimated in primiparous and multiparous cows of lactations $6-8(3.8-4.2 \%$ births) $(P<0.0001)$. Repeatability of dystocia was determined in $82.7 \%$ of cows in the following lactation $(P<0.0001)$. The stillbirth parturition rate was estimated to be $5.37 \%$ and shown to be the most important problem in the first calving compared to the second and subsequent calvings $(P<0.0001)$. Stillbirth was $11.2 \times$ higher in cows with severely difficult calving compared to cows having no calving difficulties or slight calving difficulties $(P<0.0001)$. Dystocia significantly increased the somatic cell count $(P<0.05)$ and incidence of mastitis $(P<0.001)$, in particular mastitis caused by Streptococcus agalactiae and Staphylococcus aureus.
\end{abstract}

Cattle, calf, udder health, inflammation, parturition

Difficult calving (DC), or dystocia, poses a particular problem not only in terms of pain, but also in terms of the future productivity of the dam and calf (Lombard et al. 2007). Meyer et al. (2000) reported that dystocia can include stillbirth (SB), while approximately $50 \%$ of SB are a direct result of difficult calving. Dystocia also significantly decreases lactation performance (Atashi et al. 2012). Barrier and Haskell (2011) noticed that calving difficulty impaired the milk production of dairy cows affecting the cows' productivity, and potentially impaired their health and survival. Kaya et al. (2015) found that dystocia reduced milk production during lactation in primiparous Holstein cows. Incidence of SB was higher in dystocic calvings compared with eutocic ones.

Chegini et al. (2016) demonstrated that primiparous cows had lower incidence of abortion and retained placenta but higher incidence of SB. This is probably due to the fact that the uterus of a primiparous cow has steadier ligaments and thus better ability to keep the foetus and expel the placenta after parturition but primiparous cows also have smaller pelvic dimensions that can lead to more SB at the end of lactation. López de Maturana et al. (2007) noticed that it is important to keep calving difficulties under control, especially in primiparous cows and to escape reduction of profitability in herds.

Diseases, such as mastitis, metritis and retained placenta may negatively influence the reproductive performance in dairy cows (Rajala-Schultz and Gröhn 1998; Huszenicza et al. 2005; Is obe et al. 2014). Mastitis is a multifaceted and expensive disease of dairy 
cows, which significantly reduces the milk production and performance of the dairy sector. Mdegela et al. (2009) estimated that subclinical mastitis is economically more important than clinical mastitis. Subclinical mastitis is more difficult to detect and eventually causes more production losses. Schrick et al. (2001) reported that negative consequences of mastitis on the reproductive efficiency of dairy cows are not limited to its clinical form but are also observed when the disease is at its subclinical stage. Hawari and Dabbas (2008) noticed that infectious agents commonly associated with mastitis in dairy cows are Streptococcus agalactiae and Staphylococcus aureus. Gitau et al. (2011) estimated that coliform bacteria and environmental streptococci are commonly found in the cows' environment as well. Gilbert et al. (2005) found that mastitis may influence the pattern of hormonal secretion and follicular development, due to the release of substances that inhibit the expression of receptors for gonadotropins and other reproduction-related hormones. In cases of mastitis caused by gram-negative bacteria, other reproductive disorders may occur, such as reduced oestrus expression and irregular cyclicity (Huszenicza et al. 2005; Dobson et al. 2007).

Studies by Valde et al. (1997) and Washburn et al. (2002) have demonstrated unfavourable relationships of the negative energy balance, related metabolic disorders with reproductive performance and mastitis in high-producing postpartum dairy cows. Postpartum dairy cows undergo a marked change in the energy status as their normal ovarian cycles are restored. Dairy cattle undergo a period of negative energy status in early lactation because the energy output for milk production exceeds the energy intake from feed (Risco 2004).

Dystocia with the calving related disorder can aggravate the negative energy status of cows during the postpartum period. Successful management of lactating dairy cows needs to integrate the programs of reproduction and herd health, to optimize both milk, health and reproductive performance.

The objective of this study was to determine the relationship between dystocia and SB and the prevalence of mastitis in dairy cows in order to expand the current knowledge on mastitis aetiology as a result of interactions between a combination of microbiological factors and management practices of herd reproduction.

\section{Materials and Methods}

The research was carried out at the Laboratory of Establishment of Animal Breeding Value and Selection of Lithuanian University of Health Sciences. Records of stillbirths (SB) and calving ease (CE) were obtained from the Centre of State Rural Business Development.

The study was conducted in two stages. In the first stage, the calving scores and SB were analysed in 559304 Lithuanian Black and White cows.

Each cow was assigned a dystocia score based on CE. Calving ease was determined using the following scoring: score 1 - "no problem", score 2 - "slight problems", score 3 - "cow needs assistance", score 4 - "considerable force" used to deliver calf and score 5 - "extremely difficult birth".

Still birth was definied as a calf born dead or a calf that died within $24 \mathrm{~h}$ after birth.

In the second stage, the cows were selected for evaluation of the somatic cell count (SCC) in milk, detection of microbiological udder health status after determination of CE scores, and detection of SB. Somatic cell count in milk as well as microbiological udder health status were evaluated in 1498 cows between 4-8 weeks postpartum. The SCC was determined using Somascope (CA-3A4, Delta Instruments, the Netherlands), which operates on the principle of flow cytometry technology, and was carried out at the State Laboratory for Milk Control, which operates under the requirements of ISO/IEC 17025:2005 to ensure the accuracy of milk composition and quality tests. Before milking, milk samples were collected aseptically for microbiological culture. The microbiological testing of milk samples from cows was performed at the State Laboratory for Milk Control, according to the standards of the National Mastitis Council (Harmon 1994).

\section{Statistical analysis}

Statistical procedures included descriptive statistics (mean \pm standard error), Pearson's correlation, linear regression and $\chi 2$ test were calculated by SPSS Version 15.0 for Windows and Student's $t$-test was performed in order to detect significant differences between compared groups. The results were considered significant at $P \leq 0.05$. 


\section{Results}

Analysis of the calving scores demonstrated that $48.75 \%$ of calvings were evaluated as easy (score 1), $13.43 \%$ had slight problems (score 2), $34.71 \%$ of cows needed assistance (score 3), 2.87\% needed considerable force (score 4), and $0.24 \%$ of cows had a difficult parturition (score 5).

Dystocia in relation to lactation

The majority of births by primiparous cows received a score of $1-2$, indicating that no assistance during birth was needed. Score 3 (easy calving with assistance) was assigned to $35.3 \%$ and scores $4-5$ (dystocia) to $4.1 \%$ of births by primiparous cows $(P<0.0001)$ (Fig. 1).

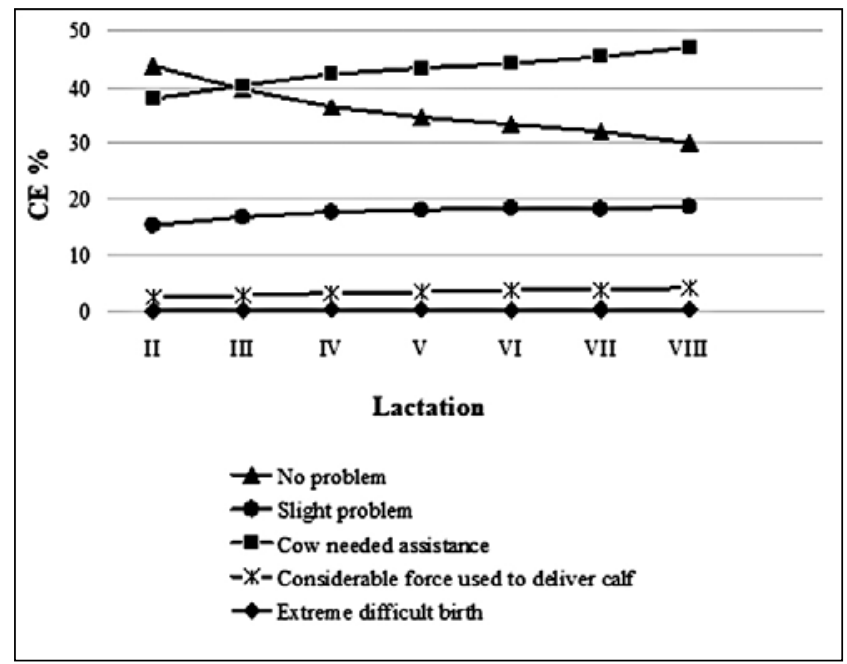

Fig. 1. Influence of lactation sequence on difficulty of birth.

$\mathrm{CE} \%$ - calving ease percentage

Studies revealed that the $\mathrm{CE} \%$ of cows births evaluated by score 1 decreased according to lactation under the linear regression equation: $\mathrm{y}=-2.631 \mathrm{x}+49.364 ; \mathrm{R}^{2}=0.9091 ; \mathrm{CE} \%$ evaluated by score 2 had tendency to increase in accordance with the following equation: $\mathrm{y}=0.9417 \mathrm{x}+12.5 ; \mathrm{R}^{2}=0.6539(P<0.0001)$.

Overall, $60.5 \%$ of all primiparous cows and $48.6-59.2 \%$ of cows in lactations 2 to 8 calved without assistance (CE scores $1-2$ ).

The number of animals requiring assistance was significantly different comparing primiparous and multiparous animals $(P<0.0001)$ and had a tendency to increase $\left(\mathrm{y}=1.5762 \mathrm{x}+34.882 ; \mathrm{R}^{2}=0.9635\right)$ by each following lactation. The analysis showed that $35.3 \%$ of primiparous heifers required assistance while this index was $37.9-47 \%$ in multiparous cows depending on their lactation.

The CE scores of 1-3 indicate relatively easy births; categories 4 to 5 indicate difficult births. The majority of extremely difficult births were found in primiparous cows and in multiparous cows in lactations 6 to 8 . For instance, $3.8-4.2 \%$ of births requiring considerable force in primiparous cows was $2 \times$ higher compared with cows in lactation 2 and 3 (Fig. 1).

Studies have shown that $82.7 \%$ of cows with the CE score evaluation of 4-5 were assessed in the following calving with higher scores i.e. 4 ("considerable force") and 5 ("extremely difficult birth") $(P<0.0001)$. 


\section{Relationship between dystocia and SB}

In this particular study, $5.367 \%$ calves out of the total of 559304 tested were stillborn. The SB rates were higher in cows of the first lactation compared to the older ones (Fig. 2). Stillbirth in cows of the first lactation was $6.5 \%$, whereas only $4.5 \%$ and $4.7 \%$ of SB cases were recorded in cows of lactations 2 and 3, respectively. As expected, first lactation heifer SB rates were $0.5-2 \%$ higher than in multiparous cows $(P<$ $0.0001)$. Starting from lactation 2 to $8, \mathrm{SB}$ increased by linear regression equations: $\mathrm{y}=0.2464 \mathrm{x}+4.2143 ; \mathrm{R}^{2}=0.9886(P<0.0001)$.

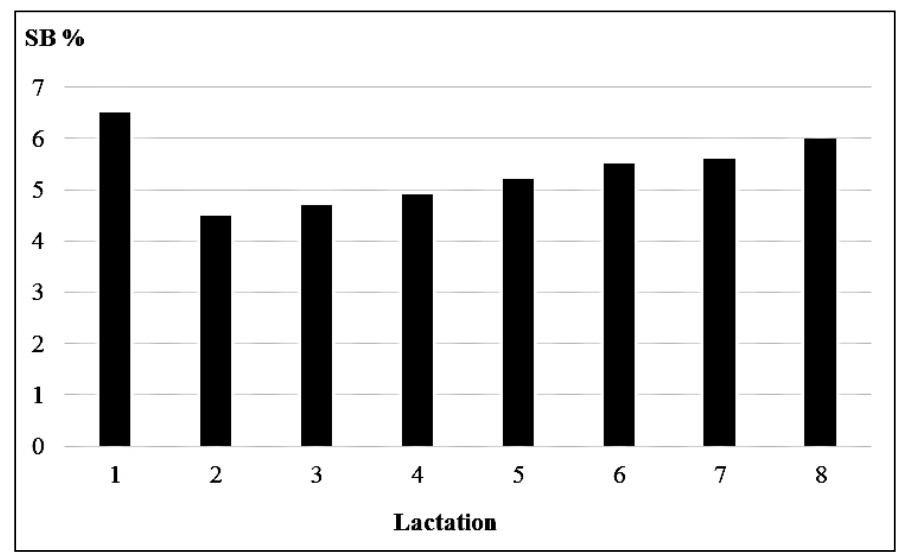

Fig. 2. Link between stillbirth and the number of cow lactations. SB \% - stillbirth percentage

Data of Fig. 3 highlight the dependence of SB on the CE of cows. It can be seen that even $89.6 \%$ of SB were obtained in cows which CE was assessed by scores 4 and $5(P<0.0001)$.

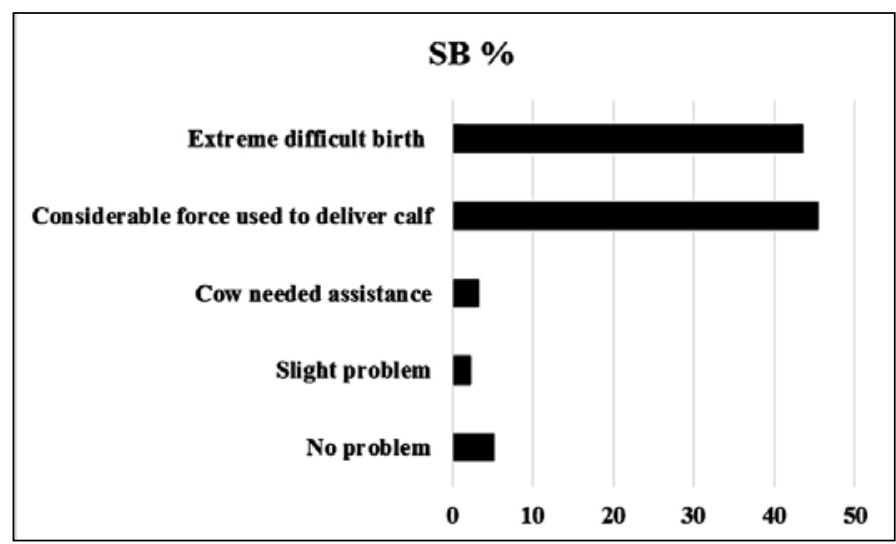

Fig. 3. Relationship between calving ease and stillbirth in cows. SB \% - stillbirth percentage

Stillbirth was $11.2 \times$ higher $(P<0.0001)$ in cows with severe difficulties in calving (CE score 4-5) compared with individuals recorded as having no calving difficulties or recorded with slight calving difficulties (CE scores 1-2). Calving difficulties had a further 
increased risk of SB. From 541921 cows with CE scores varying from 1 to 3, a total of 519.781 alive calves were obtained $(95.91 \%)$, whereas from 17383 cows with CE scores of 4 and 5, alive calves were delivered only in $54.69 \%$ cases.

Stillbirth had a clear relationship with unfavourable CE results in the following year as the frequency of SB in cows with CE scoring 3-4 increased by $1.59 \times$ in the subsequent lactation $(P<0.0001)$.

\section{Relationship between dystocia and the presence of mastitis}

Milk SCC and mastitis were significantly associated with the severity of dystocia (Table 1). The SCC in milk significantly increased with the increase of dystocia $(P<0.05)$.

Table 1. Association of dystocia with milk SCC and mastitis.

\begin{tabular}{ccc}
\hline CE score & Milk SCC $* 10^{3} / \mathrm{ml}$ & Frequency (\%) of milk samples with isolated mastitis pathogens \\
\hline 1 & $204.6 \pm 11.7^{*}$ & 29.9 \\
2 & $294.3 \pm 18.2^{*}$ & 39.7 \\
3 & $428.9 \pm 43.9^{*}$ & 45.3 \\
4 & $678.9 \pm 61.2^{*}$ & 52.8 \\
5 & $778.9 \pm 53.1^{*}$ & 60.9 \\
\hline
\end{tabular}

SCC - somatic cell count; CE - calving ease score

*Differences between all groups were significant at $P<0.05$

The prevalence of mastitis $(29.9-60.9 \%$ in lactating cows) positively related with the increase of the $\mathrm{CE}$ score. Cows with the dystocia score of 4 or 5 were more likely to experience mastitis $4-8$ weeks after calving; in particular mastitis caused by Streptococcus agalactiae and Staphylococcus aureus.

The prevalence of pathogens isolated from the mammary glands of cows with CE scores of 4-5 was 1.2-2.0 $\times$ higher $(P<0.01)$, compared to the prevalence of pathogens isolated from the mammary glands of cows with CE scores of 1-3.

In milk of cows with $\mathrm{CE}$ scores of 1-3, mixed microbiota predominated (9.1-11.0\%) together with coagulase-negative staphylococci (CNS) (5.2-8.1\%). Data of Fig. 4 showed that a CE score increased from 1-3 to 4-5 was mostly related to the increase of the prevalence of Streptococcus agalactiae (from 2.0-5.1\% to 9.3-14.9\%) and Staphylococcus aureus (from $2.9-6.0 \%$ to $11.8-13.9 \%),(P<0.0001)$.

\section{Discussion}

Reduced dairy herd profitability is associated with health and fertility costs which are also the leading causes of involuntary culling. Different studies showed that dystocia had a negative effect on reproductive performance, causing SB, retained placenta, uterine infections or increased involuntary culling (Dematawewa and Berger 1997; Rajala and Gröhn 1998; Lombard et al. 2007; Zobel 2013; Kaya et al. 2015).

The incidence of dystocia in dairy cattle varied from 2 to $20 \%$ (Lombard et al. 2007; Mee 2008; USDA 2007; Dhakal et al. 2013).

Analysis of the CE score in Lithuanian black and white dairy cows showed that $34.71 \%$ of animals needed assistance, $3.11 \%$ of cows $\mathrm{CE}$ were evaluated as "considerable force" or "extremely difficult birth". Parity had a significant influence on the CE results of cows. The majority of extremely difficult births were determined in primiparous cows and cows from lactations VI to VIII. The reported incidence of dystocia across studies was higher 


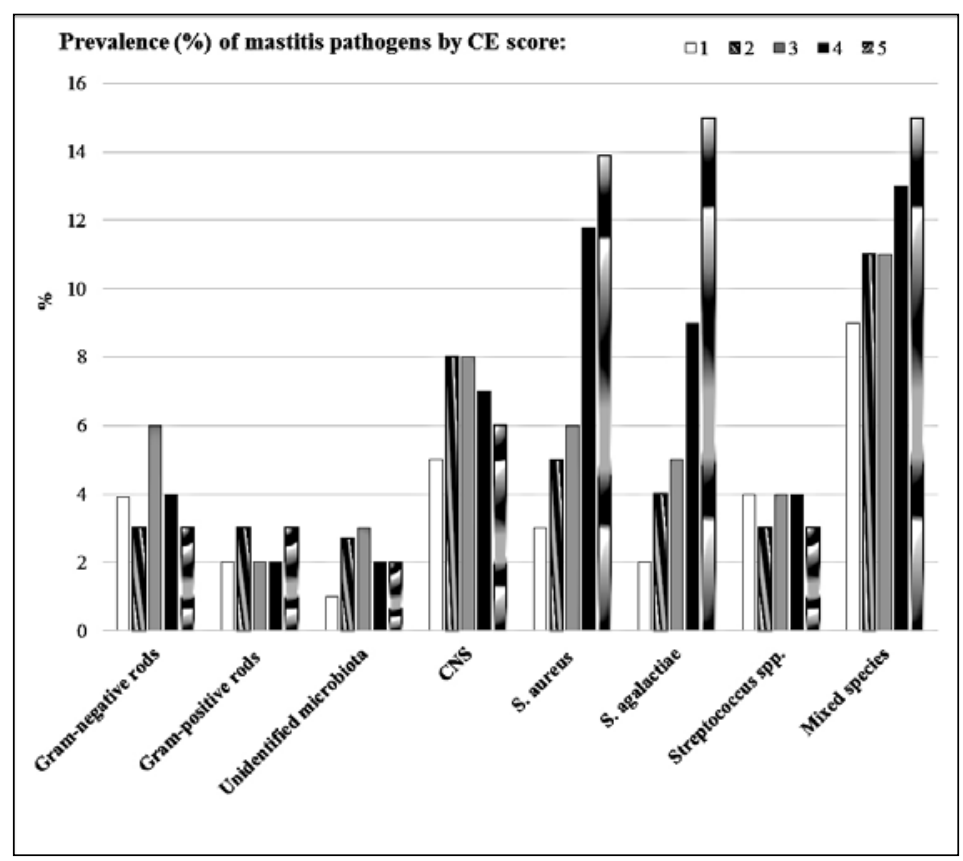

Fig. 4. Prevalence (\%) of pathogens in cows with different CE scores.

$\mathrm{CE}$ - calving ease; CNS - coagulase-negative staphylococci; 1-2-3-4-5 - calving ease points;

S. aureus - Staphylococcus aureus; S. agalactiae - Streptococcus agalactiae

in primiparous cows compared to multiparous cows (Johanson and Berger 2003; Mee 2008, Kaya et al. 2015).

Dystocia had a negative impact on the CE results in the next lactation; $82.7 \%$ of cows with a CE score of 4-5 were evaluated as "considerable force" or "extremely difficult birth" in the next calving. We found that calving difficulties further increased the risk of SB. This study showed that primiparous cows had significantly higher SB rates compared to multiparous cows.

Calf mortality is an important economic component of the farming system since it reduces the number of animals available for sale (Østerås et al. 2007) and for selection (Fuerst-Waltl and Fuerst 2010). Mangurkar et al. (1984), Meyer et al. (2000), and Atashi (2011) reported that calving difficulty was shown to be significantly associated with an increased risk of SB. Previous studies also showed that dystocia is associated with a higher incidence of SB in cows, and the incidence became higher when the degree of calving difficulty increased. Mangurkar et al. (1984) reported a close association between the severity of calving difficulty and calf losses in Holsteins, finding that percentages of SB were $3.24 \%, 4.42 \%, 26.77 \%$, and $36.96 \%$ for CE classification of unassisted, easy pull, hard pull, and surgical, respectively. Dekkers (1994) reported that the frequency of SB was substantial within the hard pull and surgery classes in Canadian Holsteins and was hardly affected by sex or parity.

Johanson and Berger (2003) found that difficult births tended to result in perinatal mortality $2.7 \times$ more than unassisted births, whereas Berry et al. (2007) estimated $8 \times$ greater likelihood of SB when assistance at calving was required. Lombard et al. (2007) reported that incidence of SB was 3.2\%, 8.4\% and 37.2\% for calves born with 
no dystocia, mild dystocia, and severe dystocia, respectively. Mild dystocia was found to increase the odds of perinatal mortality by $2.3 \times$ (Lombard et al. 2007), severe calving difficulty was found to have a much greater impact on the SB rate, with the odds increased 16 to $46 \times$ compared to unassisted calvings (Chassagne et al. 1999; Carrier et al. 2006; Lombard et al. 2007).

Heifer calves born with dystocia were more likely to be stillborn than their unassisted counterparts. The SB was $11.2 \times$ higher in cows with severe calving difficulties compared to cows recorded as having no calving difficulties or registered with slight calving difficulties. The frequency of SB in cows with CE score of 4-5 increased by $1.59 \times$ in the next lactation.

Calving difficulty increases veterinary and labor costs, culling risk, and mortality in cows and calves, decreases milk production in the next lactation, and leads to lower female fertility in the next reproductive cycle (López de Maturana et al. 2007).

Dystocia is an important factor associated with SB. It may also be concluded that dystocia significantly increases milk SCC, as the results demonstrated that dystocia had a significant effect on mastitis incidence in cows, and in particular, on mastitis caused by S. agalactiae and $S$. aureus.

The immune response to an infection of the mammary gland is of utmost importance for the health of the dairy cow. Harmon (1994) noticed that the increase in milk SCC is a consequence of the passage of polymorphonuclear cells from the blood vessels to the mammary gland in response to the release of inflammatory mediators. This mechanism could be similar in animals suffering from subclinical mastitis, causing poor reproductive performance (Schrick et al. 2001).

Parturition is a stressful process for cows and their calves (Sathya et al. 2007). Dystocia had a negative effect on the milk quality. When the calving ease scored $4-5$, the somatic cells count in milk samples significantly increased $3-3.5 \times$. The majority of extremely difficult births were determined in primiparous and multiparous cows $(P<0.0001)$. The increase of calving difficulty was associated with decreased lactation performance and also had a negative influence on udder health and microbiota. Stillbirth was higher in cows with severe difficult calving compared to cows with no calving difficulties or slight calving difficulties $(P<0.0001)$. Dystocia significantly decreased lactation performance, increased the somatic cell count $(P<0.05)$ and mastitis incidence $(P<0.001)$ caused by Streptococcus agalactiae and Staphylococcus aureus.

The obtained results can help to make better management decisions and focus efforts on the improvement of reproductive performance and health, which in turn can lead to increased profitability of cows.

\section{References}

Atashi H, Abdolmohammadi A, Dadpasand M, Asaadi A 2012: Prevalence, risk factors and consequent effect of dystocia in Holstein dairy cows in Iran. Asian-Australas J Anim Sci 25: 447-451

Atashi H 2011: Factors affecting stillbirth and effects of stillbirth on subsequent lactation performance in a Holstein dairy herd in Isfahan. IJVR 12: 24-30

Barrier AC, Haskell MJ 2011: Calving difficulty in dairy cows has a longer effect on saleable milk yield than on estimated milk production. J Dairy Sci 94: 1804-1812

Berry DP, Lee JM, Macdonald KA, Roche JR 2007: Body condition score and body weight effects on dystocia and stillbirths and consequent effects on postcalving performance. J Dairy Sci 90: 4201-4211

Carrier J, Godden S, Fetrow J, Stewart S, Rapnicki P 2006: Predictors of stillbirth for cows moved to calving pens when calving is imminent. J Dairy Sci 89 (Suppl. 1): 195

Chassagne M, Barnouin J, Chacornac JP 1999: Risk factors for stillbirth in Holstein heifers under field conditions in France: A prospective survey. Theriogenology 51: 1477-1488

Chegini A, Ghavi Hossein-Zaden N, Hosseini-Moghadam H, Shadparvar AA 2016: Factors affecting clinical mastitis and effects of clinical mastitis on reproductive performance of Holstein cows. Rev Med Vet 167: 5-6, 145-153

Dekkers JCM 1994: Optimal breeding strategies for calving ease. J Dairy Sci 77: 3441-3453 
Dematawewa CMB, Berger PJ 1997: Effect of dystocia on yield, fertility, and cow losses and an economic evaluation of dystocia scores for Holsteins. J Dairy Sci 80: 754-761

Dhakal K, Maltecca C, Cassady JP, Baloche G, Williams CM, Washburn SP 2013: Calf birth weight, gestation length, calving ease, and neonatal calf mortality in Holstein, Jersey, and crossbred cows in a pasture system. J Dairy Sci 96: 690-698

Dobson H, Smith RF, Royal MD, Knight CH, Sheldon IM 2007: The high-producing dairy cow and its reproductive performance. Reprod Domest Anim 42 (Suppl. 2): 17-23

Fuerst-Waltl B, Fuerst C 2010: Mortality in Austrian dual purpose Fleckvieh calves and heifers. Livest Sci 132: 80-86

Gilbert RO, Shin ST, Guard CL, Erb HN, Frajblat M 2005: Prevalence of endometritis and its effects on reproductive performance of dairy cows. Theriogenology 64: 1879-1888

Gitau GK, Wabacha JK, Mulei CM, Ndurumo S, Nduhiu JM 2011: Isolation rates and antimicrobial sensitivity patterns of bovine mastitis pathogens in peri-urban area of Nairobi, Kabete, Kenya. Ethiop Vet J 15: 1-13

Harmon RJ 1994: Physiology of mastitis and factors affecting somatic cell counts. J Dairy Sci 77: $2103-2112$

Hawari AD, Al-Dabbas F 2008: Prevalence and distribution of mastitis pathogens and their resistance against antimicrobial agents in dairy cows in Jordan. Am J Vet Sci 3: 36-3

Huszenicza G, Jánosi S, Kulcsár M, Kóródi P, Reiczigel J, Kátai L, Peters AR, De Rensis F 2005: Effects of clinical mastitis on ovarian function in post-partum dairy cows. Reprod Domest Anim 40: 199-204

Isobe N, Iwamoto C, Kubota H ,Yoshimura Y 2014: Relationship between the somatic cell count in milk and reproductive function in peripartum dairy cows. J Reprod Dev 60: 433-437

Johanson JM, Berger PJ 2003: Birth weight as a predictor of calving ease and perinatal mortality in Holstein cattle. J Dairy Sci 86: 3745-3755

Kaya İ, Uzmay CU, Ayyilmaz TA 2015: Effects of dystocia on milk production and reproduction in subsequent lactation in a Turkish Holstein herd. Turk J Vet Anim Sci 39: 87-95

Lombard JE, Garry FB, Tomlinson SM, Garber LPJ 2007: Impacts of dystocia on health and survival of dairy calves. J Dairy Sci 90: 1751-1760

López de Maturana E, Ugarte E, González-Recio O 2007: Impact of calving ease on functional longevity and herd amortization costs in Basque Holsteins using survival analysis. J Dairy Sci 90: 4451-4457

Mangurkar BR, Hayes JF, Moxley JE 1984: Effects of calving ease-calf survival on production and reproduction in Holsteins. J Dairy Sci 67: 1496-1509

Mdegela RH, Ryoba R, Karimuribo ED, Phiri EJ, Løken T, Reksen O, Mteng E, Urio NA 2009: Prevalence of clinical and subclinical mastitis and quality of milk on smallholder dairy farms in Tanzania. J S Afr Vet Assoc 80: 163-168

Mee JF 2008: Prevalence and risk factors for dystocia in dairy cattle: A review. Vet J 176: 93-101

Meyer CL, Berger PJ, Koehler KJ 2000: Interactions among factors affecting stillbirths in Holstein cattle in the United States. J Dairy Sci 83: 2657-2663

Østeras O, Gjestvang MS, Vatn S, Sølverød L 2007: Perinatal death in production animals in the Nordic countries - incidence and costs. Acta Vet Scand 49(Suppl 1): S1-S14

Rajala-Schultz PJ, Gröhn YT 1998: Effects of dystocia, retained placenta and metritis on milk yield in dairy cows. J Dairy Sci 81: 3172-3181

Risco CA. Managing the postpartum cow to maximize pregnancy rates. Proceedings 2004 Florida Dairy Reproduction Road Show 10. Available at: http://www.milkproduction.com/Library/Scientific-articles/ Nutrition/Managing-the-postpartum/. Accessed February 27, 2017

Sathya A, Prabhakar S, Sangha SPS, Ghuman SPS 2007: Vitamin E and selenium supplementation reduces plasma cortisol and oxidative stress in dystocia-affected buffaloes. Vet Res Commun 31: 809-818

Schrick FN, Hockett ME, Saxtom AM, Lewis MJ, Dowlen HH, Oliver SP 2001: Influence of subclinical mastitis during early lactation in reproductive parameters. J Dairy Sci 84: 1407-1412

USDA. Dairy 2007: Heifer calf health and management practices on U.S. dairy operations. N550.0110. Centers for Epidemiology and Animal Health, USDA-APHIS-VS, Fort Collins, CO. Available at: https://www.aphis. usda.gov/animal_health/nahms/dairy/downloads/dairy07/Dairy07_ir_CalfHealth.pdf. Accessed February 27, 2017

Valde JP, Hird DW, Thormond MC, Osteras O 1997: Comparison of ketosis, clinical mastitis, somatic cell count, and reproductive performance between free stall and tie stall barns in Norwegian dairy herds with automatic feeding. Acta Vet Scand 38: 181-192

Washburn SP, White SL, Green JJT, Benson GA 2002: Reproduction, mastitis, and body condition of seasonally calved Holstein and Jersey cows in confinement or pasture systems. J Dairy Sci 85: 105-111

Zobel R 2013: Endometritis in Simmental cows: incidence, causes, and therapy options. Turk J Vet Anim Sci 37: 134- 140 